\title{
Public Health Risk Assessment Due to Air Pollution in the Temir District of the Aktobe Region
}

\author{
Laura Sakebayeva*, Valentina Sabyrakhmetova, Gulsim Karashova, Perizat Aitmaganbet, Kulyan Shayakhmetova \\ Department of Hygienic Disciplines with Occupational Diseases, West Kazakhstan Marat Ospanov Medical University, Aktobe, \\ Kazakhstan, Asia
}

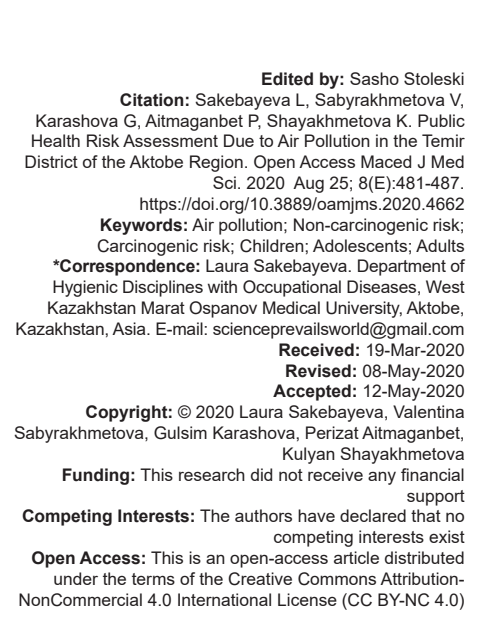

Abstract

BACKGROUND: This article focuses on the health risk assessment associated with air pollution for the population of the Temir district in the Aktobe region. The risk assessment of the effects of air pollution on public health revealed a tendency to deterioration in the health indicators of the children's population.

AIM: The research object was the population of the Temir district living near the oil and gas field Zhanazhol.

METHODS: The work was carried out according to the risk assessment methodology described in the manual R 2.1.10-1920-04. The maximum non-carcinogenic risk due to exposure to chemicals in the air basin of residential areas was established for children from 0 to 6 years of age in the Temir district.

RESULTS: A high risk of respiratory, blood, and cardiovascular diseases was observed. Sulfur dioxide, hydrogen sulfide, nitrogen, and carbon oxides contained in atmospheric air contribute to the risk of developing these diseases. The levels of carcinogenic risk to public health in the Temir district show that the maximum individual risk of oncological diseases is observed in the group of children. The risk of malignant neoplasms in adolescents is 1.2 times lower, in the male population - 1.4 times lower, on average, and in the female population - 1.3 times lower than in children. Public health risk analysis aims to select the best ways in a particular situation to eliminate or reduce risk associated with air pollution for the population.

CONCLUSION: The methodology of a comprehensive health risk analysis is a promising and developing approach in the system of monitoring the quality of the human environment and assessing environmental hazards.

\section{Introduction}

Environmental pollution has a negative impact on every resident of both the Russian Federation and the Republic of Kazakhstan. The environmental threat is probably the most important in terms of national security. Environmental safety and sustainable development of society are possible only if the state of the environment and sources of anthropogenic impact on the environment are under control, and there is an effective mechanism of environmental management.

Anthropogenic air pollution in the context of a socio-ecosystem is a global environmental and hygienic issue that makes a significant contribution to the formation of public health in urban areas. In recent years, a methodology for assessing and managing environmental pollution risks has been tested to address this issue in many regions of the Russian Federation. A risk assessment of the effect of environmental factors on public health is not only an integral part of sociohygienic monitoring but also the pinnacle of hygienic diagnosis. The implementation of this methodology makes it possible to assess the sanitary well-being of the territory, develop an effective system of preventive measures, and, based on a systems analysis, study the contributions of individual risk factors to the predicted indicator of individual or public health [1], [2], [3].

The analysis of modern literature confirms that the concept of "environmental risk" is given special significance [4], [5]. The level of environmental risk allows analyzing both natural and territorial production complexes in a unified methodological manner according to individual classes of natural and anthropogenic prerequisites for human diseases, as well as their territorial combinations. The application of the environmental risk criterion to assess the negative impact of the environment on the health and living conditions of the population creates objective prerequisites for the implementation of forecasting studies both for the total risk as a whole and for its individual forms. Domestic and foreign literature, highlighting the problems of environmental risk to public health, as a rule, connects the process of occurrence of medico-environmental tension and the emergence of new risk forms with the formation of a polluting environment complex [6], [7], [8], [9].

Under the conditions of the multicomponent and multimedia effects of environmental factors, the total value of non-carcinogenic risk for the population of the city of Aktobe was $9.41 \cdot 10-4$ (high priority), of which $84.8 \%$ 
was due to air pollution, with a high risk of harmful effects from the respiratory, central nervous, and blood systems. The total carcinogenic risk for the population amounted to $2.61 \cdot 10-2$ (high priority) and was formed due to the inhalation and oral intake of carcinogens. An industrial city is a territory of increased risk for public health: The total non-carcinogenic and carcinogenic risks are 2.1 and 4.3 times higher, respectively, in areas with a high level of anthropogenic environmental pollution [10], [11].

The purpose of this article is to give a risk assessment of the effects of air pollution on public health in the Temir district.

\section{Materials and Methods}

The research object was the population of the Temir district living near the oil and gas field Zhanazhol. The work was carried out according to the risk assessment methodology described in the manual R 2.1.10-1920-04 [12], [13]. An assessment of non-carcinogenic risk, or a calculation of the noncarcinogenic index, was carried out in fractions of the reference concentration or dose. The procedure for assessing non-carcinogenic risk involves comparing the values of the acting and reference concentrations (doses). If the ratio of these values is lower than one, then there is no risk; if it is higher, then there is a risk.

It was important to assess non-carcinogenic effects based on establishing compliance with the reference doses of priority substances. The development of non-carcinogenic effects was analyzed by comparing the actual exposure levels with the safe exposure levels (the hazard index [HI]/hazard quotient [HQ]), according to the formula:

$H Q=A C / R f C$, where $A C$ is the actual exposure level; RfC is the safe exposure level (reference concentration).

Taking into account that with the simultaneous exposure to several substances at levels below the maximum permissible concentration, the summation of biological effects is possible, the calculation of the total index (the $\mathrm{HI}$ ) is required; the summation is carried out only with factors affecting the same organs and systems of the human body.

$$
\mathrm{HI}=\mathrm{HQ}_{1}+\mathrm{HQ}_{2}+\ldots+\mathrm{HQ}_{\mathrm{n}}
$$

The information base included data from the standard statistical report (the 2TP-Air form) for a 6-year period (data on the content of the main pollutants in the atmosphere of the Temir district are presented in Table 1) and their average annual concentration according to the data of RSE "AOTSEE" of the committee on consumer rights protection under the Ministry of National Economy of the Republic of Kazakhstan. To calculate the risks, reference concentrations for chronic inhalation exposure were used (Table 2). The calculation of noncarcinogenic risks, taking into account critical organs and systems, was carried out for such atmospheric air pollutants as sulfur dioxide, nitrogen oxides, hydrogen sulfide, and carbon monoxide.

At the first stage of the study, the average annual and average daily concentrations of pollutants were calculated (Table 3). Based on these calculations, the concentration of a substance entering the body with atmospheric air was determined on the basis of $\mathrm{mg} / \mathrm{kg}$ body weight (for a specified period of time).

The HQ of non-carcinogenic effects was calculated with regard to gender (men and women) and age (children, adolescents, and adults). The HI was determined for all of the above substances with regard to the same parameters (gender and age). In addition, the HI was calculated for each critical organ and system.

The recommended standard values of exposure factors (Tables 4 and 5) were applied.

The population risk coefficients and factors (Tables 6 and 7) were applied.

Based on the results and recommended standard values of exposure factors (Tables 4 and 5), the population risk (Tables 6 and 7) was calculated for adults (men, women), adolescents, and children according to the formula:

\section{$H R I=E \times T W \times P / 10,000$}

where $\mathrm{HRl}$ is the comparative non-carcinogenic

TW is the time-weighted coefficient of health impact

$P$ is the population size

$E$ is the value of conditional exposure (t/year).

Then, the lifelong average daily dose (LADD) of one or several chronic average daily doses (ADDch) was calculated as an average weighted dose for three life periods according to the formula:

$$
\mathrm{LADD}=\frac{(\mathrm{EDb} \times \mathrm{ADDchb})+(\mathrm{EDc} \times \mathrm{ADDchc})}{\mathrm{AT}}
$$

\begin{tabular}{|c|c|c|c|c|c|c|c|}
\hline $\begin{array}{l}\text { Harmful } \\
\text { Substance Name }\end{array}$ & 2011 & 2012 & 2013 & 2014 & 2015 & 2016 & Average \\
\hline Sulfur dioxide & 4228.371 & 3445.310 & 5188.561 & 6344.767 & 702.950 & 1685.734 & 3599.282 \\
\hline Nitrogen oxides & 795.033 & 791.336 & 804.455 & 867.106 & 1001.740 & 1054.682 & 885.725 \\
\hline Carbon monoxide & 6673.394 & 6692.252 & 6932.995 & 7483.231 & 8513.920 & 8992.373 & 7548.027 \\
\hline Hydrogen sulfide & 0.00087 & 0.00089 & 0.00086 & 0.00090 & 0.00088 & 0.000862 & 0.00088 \\
\hline Hydrocarbons & 336.734 & 336.734 & 336.734 & 336.734 & 336.734 & 336.734 & 336.734 \\
\hline
\end{tabular}

Table 1: Average annual emissions of harmful substances into the air in the vicinity of the Zhanazhol gas processing plant (tons/year) 
where LADD is the lifelong average daily dose

$\mathrm{EDb}$ is the exposure duration of junior children (aged 0-6 years) -6 years.

Table 2: Reference concentrations for chronic inhalation exposure

\begin{tabular}{|c|c|c|c|}
\hline CAS & Substance & $\mathrm{RFC}, \mathrm{mg} / \mathrm{m}^{3}$ & Critical organs/systems \\
\hline $7446-09-5$ & Sulfur dioxide & 0.05 & Respiratory system \\
\hline $10102-43-9$ & Nitrogen oxide & 0.04 & $\begin{array}{l}\text { Respiratory system, blood } \\
\text { (formation of MetHb) }\end{array}$ \\
\hline $630-08-0$ & Carbon monoxide & 3 & $\begin{array}{l}\text { Blood, cardiovascular system, } \\
\text { development, central nervous } \\
\text { system }\end{array}$ \\
\hline $7783-06-4$ & $\begin{array}{l}\text { Hydrogen sulfide } \\
\text { Common hydrocarbons } \\
\text { (hexane) }\end{array}$ & $\begin{array}{l}0.002 \\
0.071\end{array}$ & $\begin{array}{l}\text { Respiratory system } \\
\text { Eyes, respiratory system, liver, } \\
\text { kidneys, central nervous system }\end{array}$ \\
\hline
\end{tabular}

EDc is the exposure duration of senior children (aged 6-18 years) - 12 years

EDa is the exposure duration of adults (aged 18 years and above) -12 years

Table 3: Average annual and average daily pollutant emissions into the atmosphere of the Temir district (tons)

\begin{tabular}{llll}
\hline Substance & Year & Day & $\begin{array}{l}\text { Average concentration } \\
\left(\mathrm{mg} / \mathrm{m}^{3}\right)\end{array}$ \\
\hline Sulfur dioxide & 3599.282 & 9.861 & 0.03 \\
Nitrogen oxides & 885.725 & 2.427 & 0.2 \\
Carbon monoxide & 7548.027 & 20.679 & 0.1 \\
Hydrogen sulfide & 0.00088 & 0.00000241 & 0.08 \\
Common hydrocarbons (hexane) & 336.734 & 0.923 & 0,4 \\
\hline
\end{tabular}

ADDchb is the chronic average daily dose of junior children, $\mathrm{mg} /(\mathrm{kg} \times$ day $)$

ADDchc is the chronic average daily dose of senior children, $\mathrm{mg} /(\mathrm{kg} \times$ day $)$

ADDcha is the chronic average daily dose of adults, $\mathrm{mg} /(\mathrm{kg} \times$ day $)$

AT is the averaging time (number of years).

Table 4: Recommended standard exposure factors

\begin{tabular}{|c|c|}
\hline Exposure factor & Value \\
\hline \multicolumn{2}{|l|}{ Exposure duration } \\
\hline Chronic exposure (adults) & 30 years \\
\hline Lifelong exposure (carcinogens) & 70 years \\
\hline Chronic exposure, children under 6 years old & 6 years \\
\hline Average life expectancy & 70 years \\
\hline \multicolumn{2}{|l|}{ Inhalation exposure } \\
\hline Inhalation rate, adult, general characteristic & $20 \mathrm{~m}^{3} /$ day \\
\hline Inhalation rate, adult, only indoor activities & $15 \mathrm{~m}^{3} /$ day \\
\hline Inhalation rate, child, $6-<18$ years old & $20 \mathrm{~m}^{3} /$ day \\
\hline Inhalation rate, child, $0-<6$ years old & $4 \mathrm{~m}^{3} /$ day \\
\hline Inhalation rate, child, $<1$ year old & $4.5 \mathrm{~m}^{3} / \mathrm{day}$ \\
\hline Inhalation rate, child, $1-12$ years old & $8.7 \mathrm{~m}^{3} /$ day \\
\hline Inhalation rate, adult woman & $11.3 \mathrm{~m}^{3} /$ day \\
\hline Inhalation rate, adult man & $15.2 \mathrm{~m}^{3} /$ day \\
\hline Inhalation rate during activity & $0.018 \mathrm{~m}^{3} /(\mathrm{kg} \times \mathrm{h})$ \\
\hline Inhalation rate during rest & $0.006 \mathrm{~m}^{3} /(\mathrm{kg} \times \mathrm{h})$ \\
\hline Exposure frequency, residential area scenario & 350 days/year \\
\hline \multicolumn{2}{|l|}{ Body weight } \\
\hline Body weight, child, $0-<6$ years old & $14-15 \mathrm{~kg}$ \\
\hline Body weight, child, $0-<18$ years old & $42 \mathrm{~kg}$ \\
\hline Body weight, adult, 18 years and older & $70 \mathrm{~kg}$ \\
\hline \multicolumn{2}{|l|}{ Total exposure time } \\
\hline \multirow[t]{2}{*}{ Duration of residence } & 30 years (90-percentile) \\
\hline & 9 years (50-percentile) \\
\hline \multicolumn{2}{|l|}{ Activity indicators } \\
\hline \multirow[t]{2}{*}{ Time spent indoors, children, 3-11 years old } & $19 \mathrm{~h} /$ day \\
\hline & $17 \mathrm{~h} /$ day (weekends) \\
\hline Time spent indoors, adults and children, $>12$ years old & $21 \mathrm{~h} /$ day \\
\hline Time spent indoors, adults & $16,4 \mathrm{~h} /$ day \\
\hline \multirow[t]{2}{*}{ Time spent outdoors, children, $3-11$ years old } & $5 \mathrm{~h} /$ day \\
\hline & $7 \mathrm{~h} /$ day (weekends) \\
\hline Time spent outdoors, adults and children, $>12$ years old & $1,5 \mathrm{~h} /$ day \\
\hline Time spent outdoors, adults & $2 \mathrm{~h} / \mathrm{day}$ \\
\hline Mobility of population (residence time in one place) & 930 (95-percentile) \\
\hline
\end{tabular}

When assessing carcinogenic risks, the average daily doses are used with regard to the expected average life expectancy of a person (70 years). Such doses are referred to as LADD. The standard equation for calculating LADD is as follows:

Table 5: Exposure factors recommended by the WHO

\begin{tabular}{lc}
\hline Exposure factor & Value \\
\hline Body weight, kg & 60 \\
Middle-aged adult & 70 \\
Adult man & 58 \\
Adult woman & 64 \\
Mean value & 60 \\
Recommended by WHO & \\
Body surface area, $\mathrm{cm}^{2}$ & 18.000 \\
$\quad$ Adult man & 16.000 \\
Adult woman & \\
Inhalation per day, $\mathrm{m}^{3}$ (8 $\mathrm{h}$ of rest, 16 h of light or non-productive activity) & 23 \\
Adult man & 21 \\
Adult woman & 15 \\
Child (10 years old) & 22 \\
Middle-aged adult & \\
\hline
\end{tabular}

$\mathrm{LADD}=[\mathrm{C} \times \mathrm{CR} \times \mathrm{ED} \times \mathrm{EF}] /[\mathrm{BW} \times \mathrm{AT} \times 365]$,

where LADD is the lifelong average daily dose, $\mathrm{mg} /(\mathrm{kg} \times$ day $)$

$C$ is the concentration of substance in atmospheric air, $\mathrm{mg} / \mathrm{m}^{3}$

$\mathrm{CR}$ is the air intake rate, $\mathrm{m}^{3} /$ day

$E D$ is the exposure duration, years

EF is the exposure frequency, days/year

BW is the human body weight, $\mathrm{kg}$

AT is the exposure averaging period for carcinogens (70 years)

365 is the number of days in a year.

Table 6: Weighted coefficients for assessing non-carcinogenic effects

\begin{tabular}{lll}
\hline $\begin{array}{l}\text { Reference (safe) dose, } \\
\mathrm{mg} / \mathrm{kg}\end{array}$ & $\begin{array}{l}\text { Reference (safe) } \\
\text { concentration, } \mathrm{mg} / \mathrm{m}^{3}\end{array}$ & $\begin{array}{l}\text { Weighted } \\
\text { coefficient }\end{array}$ \\
\hline$<0.00005$ & $<0.000175$ & 100,000 \\
$0.00005-0.0005$ & $0.000175-0.00175$ & 10,000 \\
$0.0005-0.005$ & $0.00175-0.0175$ & 1000 \\
$0.005-0.05$ & $0.0175-0.175$ & 100 \\
$0.05-0.5$ & $0.175-1.75$ & 10 \\
$>0.5$ & $>1.75$ & 1 \\
\hline
\end{tabular}

The calculation of the individual carcinogenic risk is carried out using data on the exposure level and the values of carcinogenic potential factors (slope factor and unitary risk). For carcinogenic chemicals, as a rule, the additional probability of developing cancer in an individual throughout life $(C R)$ is estimated on the basis of the LADD.

\section{$\mathrm{CR}=\mathrm{LADD} \times \mathrm{SF}$,}

where LADD is the lifelong average daily dose, $\mathrm{mg} /(\mathrm{kg} \times$ day $)$

$$
\mathrm{SF} \text { is the slope factor, } \mathrm{mg} /\left(\mathrm{kg}^{*} \text { day }\right)^{-1} \text {. }
$$

Table 7: Carcinogenic potential factors $(\mathrm{mg} / \mathrm{kg} \times \text { day })^{-1}$

\begin{tabular}{llllll}
\hline CAS & Substance & IARC & EPA & SFO & SFI \\
\hline & Common hydrocarbons (by C) & & & & 0.035 \\
\hline
\end{tabular}

The population carcinogenic risk (PCR), reflecting an additional (to the background) number of cases of malignant neoplasms that can occur throughout life due to the influence of the studied factor, is determined according to the formula: 


\section{$\mathrm{PCR}=\mathrm{CR} \times \mathrm{POP}$}

where $\mathrm{CR}$ is the individual carcinogenic risk POP is the number of the studied population, people

\section{Results}

During the study period (2011-2016), air pollutant emissions increased significantly in the Temir district. A major increase in carbon monoxide emissions was observed in 2016 (8992 tons) compared with 2011 (6673 tons).

The recommended values of reference doses and concentrations, indicating critical organs and/or systems, are presented in Table 2.

Table 3 shows the average annual and average daily pollutant emissions in tons and the concentration of pollutants in $\mathrm{mg} / \mathrm{m}^{3}$ in the atmospheric air of the Temir district.

The calculations of non-carcinogenic risks showed that the maximum health risks accrue to children in the Temir district (Table 8). In particular, the maximum $\mathrm{HQ}$ values were established for hydrogen sulfide and nitrogen oxides - 97 and 12.125 , respectively. In addition, $\mathrm{HQ}$ values greater than 1.0 were found for sulfur dioxide (1.46). The HQ for carbon monoxide was $<1$.

Table 8: The nature of non-carcinogenic health risk for the children's population (aged 0-6 years) in the Temir district

\begin{tabular}{|c|c|c|c|c|}
\hline Substance & $\begin{array}{l}\text { Dose, } \\
\mathrm{mg} / \mathrm{kg}\end{array}$ & $\mathrm{RfC}, \mathrm{mg} / \mathrm{kg}$ & $\mathrm{HQ}$ & Organ \\
\hline Sulfur dioxide & 0.073 & 0.05 & 1.46 & Respiratory system \\
\hline Nitrogen oxides & 0.485 & 0.04 & 12.125 & $\begin{array}{l}\text { Respiratory system, blood } \\
\text { (formation of MetHb) }\end{array}$ \\
\hline Carbon monoxide & 0.243 & 3 & 0.081 & $\begin{array}{l}\text { Blood, cardiovascular } \\
\text { system, development, } \\
\text { central nervous system }\end{array}$ \\
\hline Hydrogen sulfide & 1.941 & 0.002 & 97 & Respiratory system \\
\hline \multirow[t]{7}{*}{ Aggregate risk } & & $\mathrm{HI}$ total & 110.666 & \\
\hline & & $\mathrm{HI}$ development & 0.081 & \\
\hline & & HI kidneys & & \\
\hline & & $\begin{array}{l}\text { HI blood, } \\
\text { cardiovascular } \\
\text { system }\end{array}$ & 12.206 & \\
\hline & & $\begin{array}{l}\text { HI respiratory } \\
\text { system }\end{array}$ & 110.585 & \\
\hline & & $\begin{array}{l}\text { HI central nervous } \\
\text { system }\end{array}$ & 0.081 & \\
\hline & & HI liver & - & \\
\hline
\end{tabular}

The total $\mathrm{HI}$ was 110.666. The $\mathrm{HI}$ for diseases of the respiratory system takes the first place and equals 110.585, followed by diseases of the blood and cardiovascular system $(\mathrm{HI}=12.206)$, and lesions of the general development and central nervous system $(\mathrm{HI}=0.081)$.

The second highest health risk associated with air pollution was observed among adolescents in the Temir district (Table 9). The maximum $\mathrm{HQ}$ values were
Table 9: The nature of non-carcinogenic health risk for adolescents in the Temir district (aged 15-18 years)

\begin{tabular}{|c|c|c|c|c|}
\hline Substance & $\begin{array}{l}\text { Dose, } \\
\mathrm{mg} / \mathrm{kg}\end{array}$ & $\mathrm{RfC}, \mathrm{mg} / \mathrm{kg}$ & $\mathrm{HQ}$ & Organ \\
\hline Sulfur dioxide & 0.015 & 0.05 & 0.3 & Respiratory system \\
\hline Nitrogen oxides & 0.10 & 0.04 & 2.5 & $\begin{array}{l}\text { Respiratory system, blood } \\
\text { (formation of MetHb) }\end{array}$ \\
\hline Carbon monoxide & 0.05 & 3.0 & 0.017 & $\begin{array}{l}\text { Blood, cardiovascular } \\
\text { system, development, } \\
\text { central nervous system }\end{array}$ \\
\hline Hydrogen sulfide & 0.40 & 0.002 & 20 & Respiratory system \\
\hline \multirow[t]{7}{*}{ Aggregate risk } & & $\mathrm{HI}$ total & 22.817 & \\
\hline & & HI development & 0.017 & \\
\hline & & HI kidneys & - & \\
\hline & & $\begin{array}{l}\text { HI blood, } \\
\text { cardiovascular system }\end{array}$ & 2.517 & \\
\hline & & HI respiratory system & 22.8 & \\
\hline & & $\begin{array}{l}\text { HI central nervous } \\
\text { system }\end{array}$ & 0.017 & \\
\hline & & HI liver & - & \\
\hline
\end{tabular}

established for hydrogen sulfide and nitrogen oxides - 20 and 2.5, respectively. The $H Q$ for sulfur dioxide and carbon monoxide was $<1$. The health risk level for adolescents is 5-6 times lower than for children under 6 years old.

The total $\mathrm{HI}$ in this group was 22.817. Among critical organs and systems, the highest $\mathrm{HI}$ is for diseases of the respiratory system $(\mathrm{HI}=22.8)$, followed by diseases of the blood and cardiovascular system $(\mathrm{HI}=2.517)$, and lesions of the central nervous system $(\mathrm{HI}=0.017)$.

A slightly lower health risk due to chemical atmospheric factors was established for the female population of the Temir district (Table 10). In particular, the maximum $\mathrm{HQ}$ values were established for hydrogen sulfide and nitrogen oxides -15 and 1.8, respectively. The $\mathrm{HQ}$ for other analyzed chemicals was $<1$.

Table 10: The nature of non-carcinogenic health risk for the female population in the Temir district

\begin{tabular}{|c|c|c|c|c|}
\hline Substance & $\begin{array}{l}\text { Dose, } \\
\mathrm{mg} / \mathrm{kg}\end{array}$ & $\mathrm{RfC}, \mathrm{mg} / \mathrm{kg}$ & $\mathrm{HQ}$ & Organ \\
\hline Sulfur dioxide & 0.022 & 0.05 & 0.44 & Respiratory system \\
\hline Nitrogen oxides & 0.072 & 0.04 & 1.8 & $\begin{array}{l}\text { Respiratory system, blood } \\
\text { (formation of MetHb) }\end{array}$ \\
\hline Carbon monoxide & 0.036 & 3.0 & 0.012 & $\begin{array}{l}\text { Blood, cardiovascular } \\
\text { system, development, } \\
\text { central nervous system }\end{array}$ \\
\hline Hydrogen sulfide & 0.3 & 0.002 & 15 & Respiratory system \\
\hline \multirow[t]{7}{*}{ Aggregate risk } & & $\mathrm{HI}$ total & 17.252 & \\
\hline & & HI development & 0.012 & \\
\hline & & HI kidneys & & \\
\hline & & $\begin{array}{l}\text { HI blood, } \\
\text { cardiovascular system }\end{array}$ & 1.81 & \\
\hline & & HI respiratory system & 17.24 & \\
\hline & & $\begin{array}{l}\text { HI central nervous } \\
\text { system }\end{array}$ & 0.012 & \\
\hline & & HI liver & - & \\
\hline
\end{tabular}

The total $\mathrm{HI}$ was 17.252. The $\mathrm{HI}$ for diseases of the respiratory system takes the first place and equals 17.24, followed by diseases of the blood and cardiovascular system $(\mathrm{HI}=1.81)$, and lesions of the general development and central nervous system $(\mathrm{HI}=0.012)$.

A slightly lower health risk (but without significant differences compared with women) was observed among the male population of the Temir 
district (Table 11). This group has the same tendency as the female group. The $H Q$ amounted to 1.63 for hydrogen sulfide and to 13 for nitrogen oxides. The $\mathrm{HQ}$ for other analyzed chemicals was $<1$.

Table 11: Characterization of non-carcinogenic health risk for the male population in the Temir district

\begin{tabular}{|c|c|c|c|c|}
\hline Substance & $\begin{array}{l}\text { Dose, } \\
\mathrm{mg} / \mathrm{kg}\end{array}$ & $\mathrm{RfC}, \mathrm{mg} / \mathrm{kg}$ & $\mathrm{HQ}$ & Organ \\
\hline Sulfur dioxide & 0.01 & 0.05 & 0.2 & Respiratory system \\
\hline Nitrogen oxides & 0.065 & 0.04 & 1.63 & $\begin{array}{l}\text { Respiratory system, blood } \\
\text { (formation of MetHb) }\end{array}$ \\
\hline Carbon monoxide & 0.03 & 3.0 & 0.01 & $\begin{array}{l}\text { Blood, cardiovascular } \\
\text { system, development, } \\
\text { central nervous system }\end{array}$ \\
\hline Hydrogen sulfide & 0.26 & 0.002 & 13 & Respiratory system \\
\hline \multirow[t]{7}{*}{ Aggregate risk } & & HI total & 14.84 & \\
\hline & & HI development & 0.01 & \\
\hline & & HI kidneys & & \\
\hline & & $\begin{array}{l}\text { HI blood, cardiovascular } \\
\text { system }\end{array}$ & 1.64 & \\
\hline & & HI respiratory system & 14.83 & \\
\hline & & $\begin{array}{l}\text { HI central nervous } \\
\text { system }\end{array}$ & 0.01 & \\
\hline & & HI liver & - & \\
\hline
\end{tabular}

The total $\mathrm{HI}$ in this group was 14.84. Among critical organs and systems, diseases of the respiratory system are also in the first place $(\mathrm{HI}=14.83)$, followed by diseases of the blood and cardiovascular system $(\mathrm{HI}=1.64)$, and lesions of the general development and central nervous system $(\mathrm{HI}=0.01)$.

Based on the obtained results, the maximum non-carcinogenic risk due to exposure to chemicals in the air basin of residential areas is established for children (aged 0-6 years) in the Temir district. There was a high risk of respiratory, blood, and cardiovascular diseases. It should be emphasized that sulfur dioxide, hydrogen sulfide, and nitrogen oxides contained in atmospheric air contribute to the risk of developing these diseases.

The next group exposed to the increased risks of the effect of chemical environmental factors is adolescents, who also have a high risk of respiratory, blood, and cardiovascular diseases. The main contributors to the risks of developing diseases are hydrogen sulfide and nitrogen oxides, while for the rest of the chemicals, the $\mathrm{HQ}$ is below one.

A similar situation is observed in the adult population - both male and female. However, it should be emphasized that the risk of developing diseases in adults is much lower than in children and adolescents.

The calculation of the population risk for residents of the Temir district by age groups (Figure 1) showed that the female population is exposed to the maximum non-carcinogenic health risk $(\Sigma=123.79)$.

The female population is followed by adult men ( $\Sigma=121.66)$ and children $(\Sigma=104.47)$. Adolescents are at the least risk $(\Sigma=22.18)$. It should be noted that the maximum risk to public health is posed by the content of nitrogen oxides and hydrogen sulfide in atmospheric air.

The obtained data on the LADD (Figure 2) of the intake of harmful substances from atmospheric air

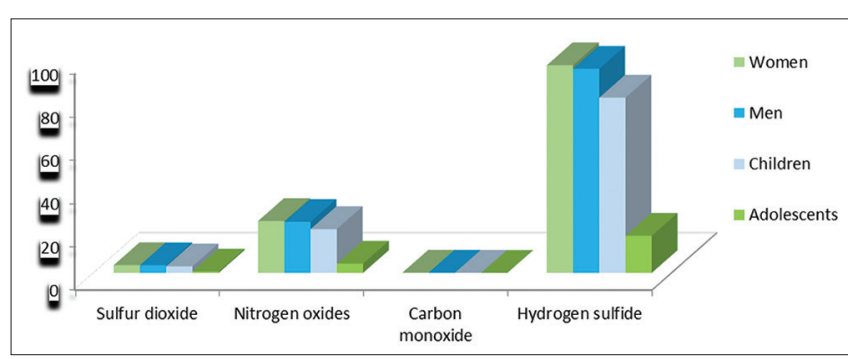

Figure 1: Population non-carcinogenic risks for residents of the Temir district

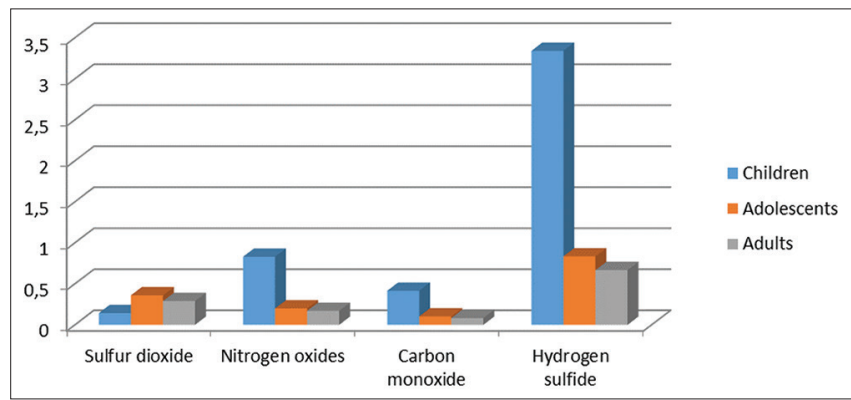

Figure 2: Lifelong average daily dose for non-carcinogenic effects, $\mathrm{mg} /(\mathrm{kg} \times$ day $)$

indicate that the maximum daily average concentrations for the entire life period fall on the group of children (0-6 years) followed by adolescents and adults.

A similar pattern is observed with common hydrocarbons (Table 12).

Table 12: The average daily intake of common hydrocarbons with atmospheric air

\begin{tabular}{lllll}
\hline Contaminants & \multicolumn{2}{l}{ Daily intake $-\mathrm{mg} /(\mathrm{kg} \times$ day $)$} & \\
\cline { 2 - 5 } & Children & Adolescents & Women & Men \\
\hline Common hydrocarbons & 0.83 & 0.069 & 0.062 & 0.056 \\
\hline
\end{tabular}

The levels of carcinogenic health risk for the population of the Temir district presented in Figure 3 show that the group of children is at the highest risk of cancer. The risk of developing malignant neoplasms in adolescents is 1.2 times lower, in the male population -1.4 times lower, on average, and in the female population 1.3 times lower than in children.

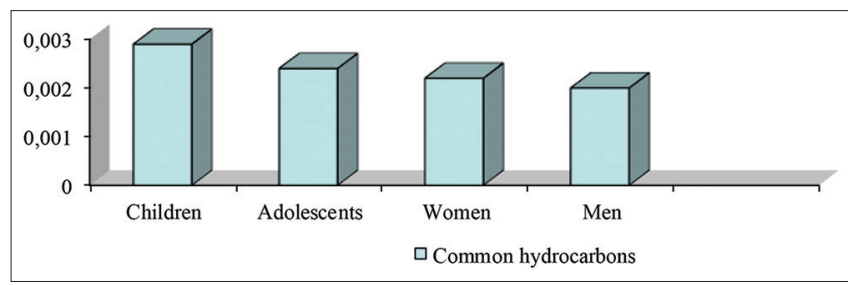

Figure 3: Individual carcinogenic risk for the population of the Temir district with regard to age

The assessment of the PCR with regard to gender and age (Figure 4) showed that children are exposed to the highest risk of cancer followed by adult women and men in the Temir district. The lowest carcinogenic risk is observed among adolescents, which can be explained by their relatively small population. 


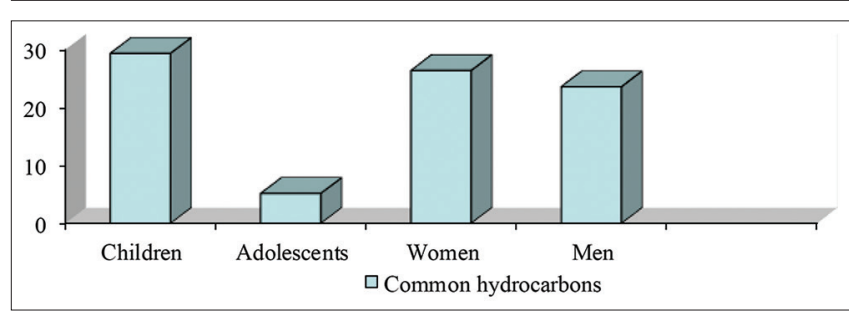

Figure 4: Population carcinogenic risk for the population of the Temir district by sex and age

\section{Discussion}

The oil and gas industry is known to be the irreplaceable driving force of the Republic of Kazakhstan. The objects of oil and gas production, processing, and storage are widely represented on the territory of the country, both already put into operation and at the planning stage. These objects, often surrounded by various settlements, pose a direct threat to the health of the surrounding population. In this connection, one should conduct an assessment of health risks from pollutant emissions associated with the future operation of an industrial facility, even before commissioning [14], [15].

Petrochemical emissions may contain toxic and carcinogenic compounds, which may be hazardous to human health. The scenario may be worse in developing countries, where health-related issues are not properly addressed, and the public may not be sufficiently informed about such a health risk [16].

The risk assessment methodology is currently an effective analytical tool for characterizing the effect of environmental factors on public health status. In addition, it has become one of the most important tools for improving the system of control and maintenance of the sanitary and epidemiological well-being of the population. Risk assessment makes it possible to get the ratio between a certain concentration of a pollutant substance and the probability of a negative impact on human health [17], [18], [19], [20].

The emergence and development of many pathological conditions depends to a large extent on the quality of the environment. Under these conditions, the scientific development and implementation of the methodology and methodological approaches of hygienic prenosological diagnostics, with regard to regional environmental features, is becoming especially relevant. Children's health is an indicator of environmental quality due to the fact that the growing body of the child with its intensive metabolism and morphofunctional characteristics determines the greatest sensitivity and susceptibility to the effects of negative environmental factors. In this regard, the results of studying children's health are considered as a reliable indicator among other criteria for the hygienic risk assessment of developing environmental pathological conditions [21], [22], [23].

Risk analysis aims to select the best ways in a particular situation to eliminate or reduce risk and includes three interrelated elements: Health risk assessment, risk management, and risk communication [24], [25], [26], [27].

Thus, the methodology of a comprehensive health risk analysis is a promising and developing approach in the system of monitoring the quality of the human environment and assessing environmental hazards [28], [29], [30], [31], [32].

\section{Conclusions}

Therefore, according to the research results, it can be concluded that the maximum non-carcinogenic risk associated with exposure to chemicals in the air basin of residential areas is established for the children's population (aged 0-6 years) of the Temir district. A high risk of respiratory, blood, and cardiovascular diseases is observed. At the same time, it should be emphasized that sulfur dioxide, hydrogen sulfide, and nitrogen and carbon oxides contained in atmospheric air contribute to the risk of developing these diseases.

The next group is adolescents who have a high risk of respiratory diseases. The main contribution to the risks of developing diseases is made by hydrogen sulfide. The $\mathrm{HQ}$ for other chemicals is below one. A similar situation is observed in the adult population - both male and female. However, it should be emphasized that the risk of developing diseases in adults is much lower than in children and adolescents.

Based on the assessment of the individual and population carcinogenic health risks for the population of the Temir district, it can be stated that the individual risk of developing cancer in all age and gender groups can be estimated as high. At the same time, it must be taken into account that among all common hydrocarbons, the calculation was made only by hexane due to the lack of data. The population risk magnitude, as a rule, should not be used to draw any direct analogies between the levels of actual cancer morbidity or mortality and the values of these risks.

\section{References}

1. Mamyrbayev AA, Sakebayeva LD. Basics of public health risk assessment. In: Basics of Occupational Medicine. Aktobe: West Kazakhstan Marat Ospanov State Medical University; 2010. p. 194-216.

2. Nemenko BA, Sharbakov AZ, Arynova GA, Ospanova GK Guidelines for Assessing the Risk of Chemical Environmental Factors to Public Health. Astana: Ministry of Health Care of Kazakhstan; 2007.

3. Yermukhanova LS, Karashova GI, Zhumagaziyeva MS Assessment of the Working Population Health in the Context of Anthropogenic Environmental Pollution. Aktobe; Kazakh Press; 2010. 
4. Amreyeva K, Omirbayeva S. The estimation of risk influence of technogenic pollution atmospheric air for health of population in the condition of Central Kazakhstan. Mod Probl Sci Educ. 2010;6:196.

5. Stepanova NV, Svyatova NV, Sabirova IK, Kosov AV. Influence and risk assessment of air pollution from vehicles to population health. Fundam Res. 2014;10:1185-90.

6. Avaliani SL, Andrianova MM, Pechennikov EV, Ponomareva OV. Environment. Health risk assessment (World Experience). Moscow: International Institute for Health Risk Assessment, Consulting Center for Risk Assessment; 1997.

7. Novikov SM, Avaliani SL, Andrianova MM, Ponomareva OV. Environment: Health Risk Assessment. Key Methodology Elements. Moscow: Consulting Center for Risk Assessment, Harvard Institute for International Development, Institute for Sustainable Communities; 1998.

8. Rakhmanin YA, Onishchenko GG. Basics of Public Health Risk Assessment Due to Exposure to Chemicals Polluting the Environment. Moscow: Research Institute of Human Ecology and Environmental Health; 2002.

9. Novikov SM. Chemical Environmental Pollution: The Basis of Public Health Risk Assessment. Moscow: Science; 2002.

10. Zasorin BV. A comprehensive characteristic of carcinogenic risk to public health in urban areas. Med J West Kazakhstan. 2008;3:99-103.

11. Zasorin BV. A comprehensive assessment of the carcinogenic load on the population of Aktobe. Med J West Kazakhstan. 2008;3:103-6.

12. Guidelines for Health Risk Assessment of Exposure to Chemical Substances Polluting the Environment ( $R$ 2.1.10.1920-04). Chief Sanitary Inspector of the Russian Federation on 05.03.2004. p. 198. Available from: http://www.docs.cntd.ru/ document/1200037399. [Last accessed on 2019 Jun 30]

13. Stepkin II, Kuzmichev MK. Assessment of a risk from exposure to atmosphere bus industrial emissions. Gig Sanit. 2009;1:9-11.

14. Bekshin ZM, Kenessary DU, Dosmukhametov AT, Kenessariyev UI, Kenessary AU, Erdenova MA. Evaluation of human health carcinogenic risks on an example of the Aral oil terminal. Bull Kazakh Natl Med Univ. 2014;3:55-7.

15. Masnavieva LB, Efimova NV, Kudaeva IV. Individual risks to adolescent health, caused by contaminating the air, and their relationship with the levels of specific autoantibodies. Gig Sanit. 2016;95(8):738-42. https://doi. org/10.18821/0016-9900-2016-95-8-738-742

PMid:29430898

16. Kampeerawipakorn $O$, Navasumrit $P$, Settachan D, Promvijit J, Hunsonti P, Parnlob V, et al. Health risk evaluation in a population exposed to chemical releases from a petrochemical complex in Thailand. Environ Res. 2017;152:207-13. https://doi. org/10.1016/j.envres.2016.10.004

PMid:27792945

17. Zabolotskikh VV, Vasilyev AV, Tereshchenko YP, Vasilyev VA. Methodology of estimation of risks to the health of population of urban territories. Izvestia Samara Sci Cent Russ Acad Sci 2016;18:19-24. https://www.cyberleninka. $\mathrm{ru} / \mathrm{article} / \mathrm{n} / \mathrm{metodologiya-otsenki-riskov-zdorovyu-}$ naseleniya-urbanizirovannyh-territoriy/viewer. [Last accessed on 2019 Jun 30]

18. Piersanti A, Adani M, Briganti G, Cappelletti A, Ciancarella L, Cremona $\mathrm{G}$, et al. Air quality modeling and inhalation health risk assessment for a new generation coal-fired power plant in Central Italy. Sci Total Environ. 2018;644:884-98. https://doi. org/10.1016/j.scitotenv.2018.06.393 PMid:30743886

19. Petrovic M, Sremacki M, Radonic J, Mihajlovic I, Obrovski B, Miloradov MV. Health risk assessment of PAHs, PCBs and OCPs in atmospheric air of municipal solid waste landfill in Novi Sad, Serbia. Sci Total Environ. 2018;644:1201-6. https://doi. org/10.1016/j.scitotenv.2018.07.008
20. Huang S, Shao G, Wang L, Wang L, Tang L. Distribution and health risk assessment of trace metals in soils in the golden triangle of Southern Fujian Province, China. Int J Environ Res Public Health. 2018;16(1):E97. https://doi.org/10.3390/ijerph16010097 PMid:30602676

21. Onishchenko GG, Novikov SM, Rakhmanin YA. Integrated Determination of the Anthropotechnogenic Load on Water Bodies, Soil, and Atmospheric Air in Residential Development Areas. Moscow: Research Institute of Human Ecology and Environmental Health; 1996. Available from: http://www.docs. cntd.ru/document/1200071315. [Last accessed on 2019 Jun 30].

22. Shashina TA. Comparative Carcinogenic Efficacy of lonizing Radiation and Chemical Compounds. Moscow: Energoatomizdat; 1998.

23. Zhang $\mathrm{H}$, Mao $\mathrm{Z}$, Huang $\mathrm{K}$, Wang $\mathrm{X}$, Cheng $\mathrm{L}$, Zeng $\mathrm{L}$, et al. Multiple exposure pathways and health risk assessment of heavy metal (loid)s for children living in fourth-tier cities in Hubei Province. Environ Int. 2019;129:517-24. https://doi. org/10.1016/j.envint.2019.04.031

PMid:31158597

24. Avaliani SL, Bushtuyeva KA, Novikov SM, Onishchenko GG. Basics of public health risk assessment due to exposure to chemicals polluting the environment. Res Inst Hum Ecol Environ Health. 2002. Available from: https://www.files.stroyinf.ru/ Data2/1/4293853/4293853015.pdf. [Last accessed on 2019 Jun 30]

25. Bykov AA, Zemlyanaya GM, Solenova LG, Furman VD. Methodological Guidelines for the Analysis and Management of Public Health Risk Due to Exposure to Harmful Environmental Factors. Moscow: Ankil; 2002.

26. Morgenstern RD, Shih J, Sessions SL. Comparative risk assessment: An international comparison of methodologies and results. J Hazard Mater. 2000;78(1-3):19-39.

PMid:10978559

27. Rahman MS, Khan MD, Jolly YN, Kabir J, Akter S, Salam A. Assessing risk to human health for heavy metal contamination through street dust in the Southeast Asian Megacity: Dhaka, Bangladesh. Sci Total Environ. 2019;660:1610-22. https://doi. org/10.1016/j.scitotenv.2018.12.425

PMid:30743952

28. Xu X, Zhang $\mathrm{H}$, Chen J, Li Q, Wang X, Wang W, et al. Six sources mainly contributing to the haze episodes and health risk assessment of PM2.5 at Beijing suburb in winter 2016. Ecotoxicol Environ Saf. 2018;166:146-56. https://doi. org/10.1016/j.ecoenv.2018.09.069

PMid:30265878

29. Wang $P$, Zhao N, Cui $Y$, Jiang W, Wang L, Wang Z, et al Short-chain chlorinated paraffin (SCCP) pollution from a CP production plant in China: Dispersion, congener patterns and health risk assessment. Chemosphere. 2018;211:456-64. https://doi.org/10.1016/j.chemosphere.2018.07.136 PMid:30077940

30. Zhang X, Zhao XM, Meng XJ, Wang XY, Yang S, Xu XP, et al. Particle Size distribution and human health risk assessment of heavy metals in atmospheric particles from Beijing and Xinxiang during summer. Huan Jing Ke Xue. 2018;39(3):997-1003. PMid:29965442

31. Doabi SA, Karami M, Afyuni M, Yeganeh M. Pollution and health risk assessment of heavy metals in agricultural soil, atmospheric dust and major food crops in Kermanshah province, Iran. Ecotoxicol Environ Saf. 2018;163:153-64. https:// doi.org/10.1016/j.ecoenv.2018.07.057

32. Weerasundara L, Magana-Arachchi DN, Ziyath AM, Goonetilleke A, Vithanage M. Health risk assessment of heavy metals in atmospheric deposition in a congested city environment in a developing country: Kandy City, Sri Lanka. J Environ Manage. 2018;220:198-206. https://doi.org/10.1016/j.jenvman.2018.04.036 PMid:29778956 